\title{
Combating Fraud and the Challenge of Political Willingness: Evidence from Nigerian Public Sector
}

Shehu Umar Sa'id ${ }^{1 *}$, Khairul Saidah Abas Azmi ${ }^{2}$ Abdullahi Bala Alhaji ${ }^{3}$, Ali Usman ${ }^{4}$, Idrith Ahmed Yusif ${ }^{5}$

${ }^{1}$ Department of Accountancy, School of Business Studies, Federal Polytechnic, Bauchi, Nigeria, Email: shehumarsaid@gmail.com

${ }^{2}$ School of Business and Accountancy, University of Malaya, Malaysia. Email: kairul saidah@um.edu.my ${ }^{3}$ Department of Accounting, School of Business Studies, Umaru Ali Shinkafi Polytechnic Sokoto State, Nigeria. Email: abdullahibala007@gmail.com

${ }^{4}$ Department of Accountancy, School of Business Studies, Federal Polytechnic, Bauchi, Nigeria; Email: aulame1434@gmail.com

${ }^{5}$ Department of Accountancy, School of Business Studies, Federal Polytechnic, Bauchi, Nigeria; Email: idrisahmady@gmail.com

*Corresponding Author: Shehu Umar Sa'id, Department of Accountancy, School of Business Studies, Federal Polytechnic, Bauchi, Nigeria, shehumarsaid@gmail.com

\begin{abstract}
The purpose of this paper is to explore the lack of political willingness in Nigeria as a challenge to combating fraud among public employees. This study is a qualitative approach. The sources of data collection involve government reports, newspapers and interviews. In all, 12 participants were employed for the study. The study found that a lack of political willingness in Nigeria shows a persistent challenge to combat fraud. Our findings suggest that (1) political intervention, (2) party system or political party and (3) lack of commitment from the government make fraudulent practices in Nigerian public sector (NPS) perennial. Thus, it has hindered the effort to combat fraud in NPS. This study has practical implications for regulators (like CBN), and anti-corruption bodies such as EFCC, ICPC, AMCON, and $C C B$. The study could perhaps redirect their efforts and eases the way of mitigating fraudulent practices in Nigeria's public sector. The study also has an academic contribution to the body of knowledge and insight to the literature. This paper is original and unique in its form and has the value on fraud prevention, detection of corruption, combating the contemporary fraud cases in the Nigerian public sector, and useful to those who might cherish its standing.
\end{abstract}

Keywords: Fraud, Lack of Political Willingness, Challenges, Public Sector, Nigeria

\section{INTRODUCTION}

The rate of unethical behavior among Nigerian public officials has reached the level that fewer people enjoy the greater part of the national revenue and the remaining goes to a large number of people. Despite the huge revenue from oil and other sources, yet, over $80 \%$ of Nigerians live a poverty life and only very few live above the poverty line (Mansor, 2015a). Karwai (2002) reveals that fraud has 
turned out to be a daily routine among the Nigerian public officials where everybody is trying to grab the opportunity of his/her official power. Thus, thereby violating the entrusted obligation confined on him or her by defrauding the state own treasury for their personal gain. Nigeria was ranked $33^{\text {rd }}$ out of 177 countries as part of the most corrupt nation as reported by Transparency International (2013).

In spite of the abundant natural resources and human skills in Nigeria, fraud and bribery are the key elements that clog the development of Nigeria and has continually hindered the realization of ethical national objectives (ljewereme, 2015). The government has been struggling to reduce the level of corruption through legal measures and integrity, yet little success is recorded, between $2003-2012$ the government of Nigeria was estimated to lose over $\$ 500$ billion to corrupt elites (Albert \& Okoli, 2016). The public misappropriation in the Nigerian economy had extremely and negatively affected national development. Ranging from negative economic effects, poor standard of leaving, poor educational background, insecurity and tarnishing national image globally (Adebisi \& Gbegi, 2015).

In Nigeria, the agency saddled with the responsibility of collecting and remitting the revenue to the Federal government, which is Federal Inland Revenue Service (FIRS), oil firms, revenue boards have been confirmed to get involved in the huge public sector accounting fraud (Auditor, 2016). The massive embezzlement of public funds and money laundering among the Nigerian government officials prompt a serious concern to the public. Izedomin and Mgbame (2011); Okoye and Gbegi (2013) revealed that there is an upsurge in fraudulent practices in the Nigerian public sector. This study suggests that combating fraudulent practices in the Nigerian public sector is a challenge because of the absence of a political will. Part 2 of this paper discussed the concept of fraud, political willingness lack of which results in the challenge of combating fraud and the challenges of combating fraud. The methodology is presented in section 3 of this paper. Empirical findings of the study come in section 4 of the paper. Section 5 present the discussion and section 6 provide the conclusion and recommendation.

\section{LITERATURE REVIEW}

This section provides the literature review in the following subheadings:

FRAUD

Although there is no comprehensive definition of the term fraud, various organizations viewed the term fraud differently (Eyo, 2017). Therefore, having a precise meaning of the term fraud becomes a difficult task in academic literature. It can either be viewed from a legal perspective; academic view or based on experiences. The legal definition of fraud emerged in England and Wales after the introduction of the Fraud Act by 2006 (Onuora, Akpoveta, \& Agbomah, 2018). From the legal perspective, the term fraud is viewed as an act of repudiating a person's entitlement or right unethically for the selfish interest of the perpetrating party (Taiwo, Agwu, Babajide, \& Isibor, 2016). Fraud is the propensity and tendency to act wrongly in such a way to be harmful to others. It is an attempt of sabotaging regulations by using a trick to take what belongs to the public and use them for personal benefit (Mukoro, 2013). Fraud is a purposeful and deliberate act designed basically to swindle and deceive another individual or group of an individual for the benefit of the perpetrator (Amiram et al., 2018). Fraud means something entirely different to a different individual under different situations (Onuora et al., 2018).

\section{Political Willingness}

Political willingness is a critical and preliminary fact for sustainable and efficient anti-corruption policies and programs (Stapenhurst \& Kpundeh, 1999). Political willingness determines the success or failure of the effort of combating public fraud in any economy (Ankamah \& Manzoor E Khoda, 2018). This fortifies the belief that the absence of political willingness from the side of government resulted in a lack 
of commitment to address the financial mismanagement. This hinders the achievement of other national objectives (Hope Sr, 2017). Political willingness is the fundamental factor for the successful implementation of any anti-craft policies as the leaders can make effective policies and ensure the fair implementations of the policies (J. S. Quah, 2016). Political willingness alludes to the dedication of topgovernment officials to exterminate fraudulent activities within their economy or countries (Quah, 2006). Political willingness is the dedication of public leaders to undertake certain actions that ensure the attainment of set objectives, a corrupt-free organization that improves the standard of living of a common citizen (D. W. J. U. B. Brinkerhoff, 2010).

\section{Challenges of Combating Fraud}

Most of the political regime that came into power in Nigeria promised to combat fraudulent activities and prosecute the fraudsters, unfortunately, these politicians get involved in most of these fraudulent practices (Dalton, Powell Jr, \& Strøm, 2014). This unethical behavior of some of the Nigerian politician makes fraudulent practices in the Nigerian public sector perennial. Another factor may be attributed to bias application of the laws as the anti-graft bodies turn to be a political watchdog and treat to the opposition, acting contrary to the provision of the laws (Albert \& Okoli, 2016). These unethical behaviors exhibited by the Nigerian politician become a treat to the economic development of the nation. It was argued that no country world appreciates speedy economic development without good governance (Crosby \& Bryson, 2005). Thus, economic growth and development is always the outcome of good governance. The Nigerian problem is not associated with land, water, climate or anything else but the unwillingness of the leaders to deliver their responsibility due to a corrupt mindset (Crosby \& Bryson, 2005). Statistically, over $75 \%$ of Nigerian fraudulent cases are mostly perpetrated by top government officials (Okoye, 2016).

Then again, Nigerian military systems, especially from 1985 to 1999, were known to be associated with high financial indiscipline, money laundering, bribery and fraudulent activities (Fagbadebo, 2007). The military system of administration was described by fascism where the right to expressing option was denied. This made an open door for the military rulers to act fraudulently. This similarly constituted a challenge to mitigate the menace of fraudulent activities among government officials in Nigeria (Okekeocha, 2013). These fraudulent practices exhibited by military rulers become perennial and out of control especially during the administrative period of three military head of state, that is from 1985 to 1999, these are General Ibrahim Babangida, General Sani Abaca and General Abubakar Abdulsalam where financial scandal and defrauding became the typical attitude of public officials (Duke \& Agbaji, 2017). During the military administration, coup d'état was the means of establishing a government. The business of the day then was for one government to overthrow another government and established a new one. This also affected the effort to mitigate fraudulent activities.

Despite extensive effort aim to address the problem of fraud in developing countries, the problem is still incessant in Nigeria a developing country regime (Eyisi \& Ezuwore, 2014). Part of the efforts is the establishment of the Institute of Corrupt Practices Commission (ICPC) by the year 2000 and the Economic and Financial Crime Commission (EFCC) after two years, mainly to address the problem of financial scandal (Mansor, 2015b). The government has been struggling to reduce the level of fraudulent practices through legal measures and integrity, yet little success is recorded, between 2003 - 2012 the government of Nigeria was estimated to lose over $\$ 500$ billion to corrupt elites (Albert \& Okoli, 2016). Another factor that remained a challenge in preventing fraudulent behavior is the lack of political willingness.

Lack of political willingness from the side of government is another challenge of combating fraud in the Nigerian public sector. Political will as earlier defined is a critical and preliminary fact for sustainable and efficient anti-corruption policies and programs (Stapenhurst \& Kpundeh, 1999). Lack of interest by the Nigerian politician to curtail financial crime allow abusive practices to continue and eventually create an avenue for misuse of public fund. Although there are numerous attempts by the government and regulatory agencies to address the problem of financial mismanagement in Nigeria yet the fraudulent 
cases seem to be increasing because of the absence of political interest from the side of a politician (Ugoani, 2015).

\section{METHODOLOGY}

Due to the massive upsurge in fraudulent practices in the Nigerian public sector and this phenomenon is extremely important and very complex that cannot just be condensed by formulating hypotheses that can be quantitatively tested. Therefore, the explorative approach is necessary (Bowen, 2005; Buckler, 2008; Creswell \& Creswell, 2017). An in-depth interview was conducted with 12 participants including (3) accountants, (3) auditors, (2) legal practitioners, (2) staff of EFFC and (2) staff of FIRS. This is aimed to answer the following research question: RQ1. What are the challenges facing combating fraud in the Nigerian public sector? RQ2. Why the problem of fraud in NPS is still incessant in Nigeria despite extensive effort to address the matter? The interview is carefully recorded with a good recording instrument after which the researchers transcribed the audio into text. The researchers used the transcribing software by listening to the audio slowly and repeatedly to ensure that all the respondents' views are captured accurately. This process promotes the reliability and validity of the finding (Healy \& Perry, 2000; Ritchie, Lewis, Nicholls, \& Ormston, 2013)

\section{RESULTS AND FINDINGS}

In most of the African countries, fraudulent literature, evidenced (Abdulai, 2009; Asongu, 2013; D. W. Brinkerhoff, 2010) indicate the persistence increase of fraudulent activities among public servant exacerbated by lack of political will to investigate many allegations of dishonesty involving some-high public officers. Lack of interest by the politician to address the fraudulent behavior, corruption and other financial crime allow abusive practices to continue and finally paves the way to misappropriation. Although there are several attempts to combat the menace in Nigeria, the phenomenon is persisting globally due to the absence of a strong political will or lack of it completely (Ugoani, 2015). The view of the respondents (ACC3, ACC4, AUD2, EFCC2, LLB1, and FIRS2) disclosed that lack of political interest by the Nigerian government to fight financial crime is the major challenge faced in preventing fraud. For instance, AUD2 noted that;

"...the government is not serious at all in addressing the fraudulent matters, the government just announces publicly that we are, or we have taken a war against corruption, bribery, fraudulent and unethical act, all these must be stopped but the fraud and misappropriation are still ongoing. That is to say, all media information is just a mere saying to deceive the public and the entire world that the government is serious in fighting mismanagement while in real sense they are not" (AUD2).

\section{The FIRS2 explicitly explained that:}

"it is after the public officials have looted everything then the government or agency responsible for executing fraudsters will now claim to have arrested the person after such a person leave the office. So, if the government is willing to stop fraud, the government should begin by having an active mechanism that will take care of public finances" (FIRS2).

Equally important, ACC4 give one example on what happens in a prominent fraud case:

"...there is a video clip going viral on social media that Mr. A is seeing clearly on the video clip collecting a bribe from a contractor, although this is a bribe, yet nothing is done against him because he is from the side of the government" (ACC4) [the parties' identities, in this case, is hidden for confidentiality purpose].

The lack of political will is further justified by LLB1. He states that: 
"most of the rules are only on paper but not in reality, if the government is really serious then necessary action would have been taken against the perpetrators because nobody is above the law, hence, the government should ensure that those who are behind it or those who perpetrate it are being appropriately punished. There have been cases of misappropriation of public funds, fraud, and other financial crime, so many allegations on public official but only a few were arrested, and none was prosecuted because of the absence of political will from the side of the government" (LLB1).

The above responses of the respondents show that the government effort to address the problem of misappropriation among the public servant is very weak and a mere saying publicizing of the fights of fraud. The data also revealed that there are no sound laws as regards to fights against fraudulent activities. This is justified by the limited number of convictions. Mostly, the perpetrators are not punished, these are part of the reasons why the attempt and recommendations to prevent fraud in the Nigerian public sector has failed to fix the problem. The interview data also attributed the challenge to combat the mismanagement of public funds among the Nigerian public employees to the political intervention. Which is coercive interference by one state in the affairs of another or interference of a particular group of people into the affairs of the state. AUD3 opined that:

"politicians intervene in the affairs of the EFCC and ICPC to direct what should be done be it is right or not and this is called political intervention, they will not allow the work to go smoothly or the laws to work by the provision of the constitution. Therefore, political intervention is one of the bottlenecks that rendered the attempt to combat fraud unsuccessful" (AUD3).

The responses of the respondents above indicated that the actions of the Economic and Financial Crime Commission (EFCC), Institute of Corrupt Practices Commission (ICPC) and Code of Conduct Bureau (CCB) are influenced by the Nigerian politicians. This means that anti-graft bodies are directed on what to and not to do by the top government official. This, therefore, makes the reasons behind their establishment irrelevant. In a contrasting view, the respondents pointed out the political system' or 'party system' as one of the factors that remain as a challenge of fraud prevention among the Nigerian public employees. This is illustrated by AUD1:

"...political system or party system contributes to the failure of the attempt by the government to address the problem of public misappropriation and pave ways for unethical behavior. Most of the executive officers or anybody holding a public office misappropriate fund and then move to the ruling party and get his litigation file swept under the carpet or the case close and it is very obvious in Nigeria. These affect the units, department and the entire system that supposed function efficiently to address the situation ineffective" (AUD1).

\section{One clear example was given by LLB1 when he stated that:}

"There have been information or news circulating on the Nigerian media alleging that Mr. B who served as a governor for eight years in one of the Nigerian particular state misappropriated over N25 billion state fund. Mr. B was arrested brought before the court but subsequently, Mr. B moved and joined the ruling party and the allegation or case is withdrawn. Presently, Mr. B, is part of the Nigerian lawmaking body being a serving senator. Lack of political will to fight the misappropriation or corruption and to ensure that those who are behind it or those who perpetrate it are being appropriately punished is the major challenge of fraud prevention in Nigeria." (LLB1). [The parties' identities, in this case, is hidden for confidentiality purpose].

\section{ACC2 has presented another example where he stated that:}

"Mr. C was one time a governor from the southern part of Nigeria and was allegedly by the EFCC of misappropriating over 97 billion Naira public funds through the sale of the state property. During the... [year is hidden for confidentiality purpose] general election, Mr. C moved to the ruling party and participated actively in ensuring the success of the election and was appointed a minister after winning the election" (ACC 2). [The parties' identities, in this case, are hidden for confidentiality purposes].

The interview data of the respondents above revealed that the favoritism of the ruling party is another bottleneck in the fights against fraudulent activities among the Nigerian politicians. Bing that the 
politicians that belong to the ruling party are save from being prosecuted. This creates an avenue for most of the politicians that defraud public resources to decamped to the ruling party just to be at the safer hands. Complementary to the political intervention and party system the data sheds more-light on lack of commitment from the side of government to fight the fraudulent activities. Lack of commitment is an indication that a member or a certain group of people or laws are not fully operated. AUD1 believed that a lack of commitment from the side of government remains a serious challenge in dealing with fraudulent issues. The AUD1 noted:

"some of the laws meant to prevent the occurrence of unethical behavior or safeguard public assets in Nigerian Public Sector are not operative, so being not operative definitely renders the attempt to curtail fraudulent activities not realizable as most of these attempts are just shadow attempts not real attempts from the side of government. Thus, shadow attempt remains a challenge in curtailing fraud in the Nigerian public sector. Moreover, the success or failure of the attempts to curtail fraudulent practices lies in the soundness and effectiveness of the judicial system and the rate of conviction" (AUD1).

The aforementioned responses of the participants illustrated the level at which the respondents gave emphases or too many regards on lack of political will which contributing (a) political intervention and (b) party system or political party as a great challenge faced in the prevention of fraudulent activities among the Nigerian public employees.

\section{DISCUSSION}

The interview data acknowledged that there is a lack of political will in combating fraud in the Nigerian public sector. This signified that without political will from the side of government the effort to address fraudulent activity will not succeed. This is in line with the findings of (J. S. Quah, 2017), Singapore's success in fighting corruption and other fraudulent act can be credited to the political will of the government action and the effectiveness of the agencies fighting the menace by ensuring the laws enforce fairly on all. Political will is the fundamental factor for the successful implementation of any anticraft policies as the leaders can change positively because they make the rules and determine how it works (J. S. Quah, 2016). It determines the success or failure of the attempt to combat financial mismanagement in any organization. It results in lack of commitment to combat fraudulent activities and pursue other significant national goals (Hope Sr, 2017).

The futile of Indian anti-graft strategy to curb fraudulent activities in Indian is attributed to a lack of political will of their top-government official that led to unfair enforcement of the anti-graft laws (Quah, 2008). Where there is sound and effective anti-corruption bodies while the political will is weak, the enforcement of anti-corruption laws undermines their efficiency (Quah, 2006). For the past five decades in Asian countries, only Singapore and Hong Kong appreciate relatively low degrees of fraudulent activities, this is due to sound political will demonstrated by the two countries (Quah, 2006). Further states that Malaysia's anticorruption bodies have not effectively combat fraud due to weak political willingness from the side of government. Nigeria as a country under the current administration of President Buhari tries to ensure the autonomy of the existing anti-corruption bodies yet; the fraudulent activities are still ongoing. Sound policies alone will not usually curb fraudulent acts if the public leaders do not have the political will to dedicate the needed resources to the anti-graft bodies (Abdulai, 2009). The presence of political will must not be presumed on the basis of sound policies, number of anti-graft bodies but on those initiated the establishment of the policies and anti-graft bodies (Kpundeh, 1998, 2000). This is line with the findings of (Brinkerhoff, 2000; Catalogs, Monitor, \& Outlook, 2000; Williams \& Doig, 2004), who argue that without political will from the side of political leaders no anti-corruption reforms is bound to succeed. Thus, political will is the fundamental component for a sound and effective anti-graft bodies as the politicians must demonstrate their commitment toward fighting the unethical act through various measure such as (a) adequate materials for curbing fraud; (b) complete anti-corruption rules/laws; (c) full autonomy to anti-graft agencies; and (d) appropriate punishment to those who found wanted irrespective of their official rank (Quah, 2004). In Nigeria, the first manifestation of the absence 
of political willingness in combating fraudulent activities is the common man perception that the antigraft bodies such as EFCC, ICPC, and CCB are wit hunting dog for political opponents and the selective enforcement of their laws (ljewereme, 2015).

\section{CONCLUSION}

In conclusion, fraud has turned into a threat to world economic development that necessitates the maximum intervention of different anti-graft bodies globally. Despite the numerous efforts aim to mitigate fraudulent activities, however, different types of fraud are undoubtedly remained to rise in returns. Combating fraudulent behavior in Nigeria is a virtually challenging task this is because the Nigerian government has so far not demonstrated a sound and effective political will to address the menace of fraud as the anti-graft laws are unfairly enforced. The government efforts are very weak and a mere saying publicizing of the fights of fraud. The actions of (EFCC), (ICPC) and (CCB) are influenced by the Nigerian politicians. The favoritism of the ruling party is another bottleneck in the fights against fraudulent activities among the Nigerian politicians It is acknowledged that further study with a larger sample from both the public and private sectors could be conducted it may perhaps yield a different result. The study's findings could also be tested quantitatively.

\section{Reference:}

Abdulai, A. G. (2009). Political will in combating corruption in developing and transition economies. Journal of Financial Crime.

Adebisi, J., \& Gbegi, D. (2015). Fraud and the Nigerian public sector performance: The need for forensic accounting. International Journal of Business, Humanities, and Technology, 5(5), 67-78.

Albert, A. T., \& Okoli, F. (2016). EFCC and the politics of combating corruption in Nigeria (2003-2012). Journal of Financial Crime, 23(4), 725-747.

Amiram, D., Bozanic, Z., Cox, J. D., Dupont, Q., Karpoff, J. M., \& Sloan, R. (2018). Financial reporting fraud and other forms of misconduct: a multidisciplinary review of the literature. Review of Accounting Studies, 23(2), 732-783.

Ankamah, S. S., \& Manzoor E Khoda, S. (2018). Political will and government anti-corruption efforts: What does the evidence say? Public Administration and Development, 38(1), 3-14.

Asongu, S. A. (2013). Fighting corruption in Africa: do existing corruption-control levels matter? International Journal of Development Issues.

Auditor, G. (2016). Auditor-General Annual's Report On The Account Of Federation Of Nigeria. Abuja Nigeria: Federal Government of Nigeria.

Bowen, G. A. J. T. Q. R. (2005). Preparing a qualitative research-based dissertation: Lessons learned. $10(2), 208-222$.

Brinkerhoff, D. W. (2000). Assessing political will for anti-corruption efforts: an analytic framework. Public Administration and Development: The International Journal of Management Research and Practice, 20(3), 239-252.

Brinkerhoff, D. W. (2010). Unpacking the concept of political will to confront corruption. U4 Brief.

Brinkerhoff, D. W. J. U. B. (2010). Unpacking the concept of political will to confront corruption.

Buckler, K. J. J. O. C. J. E. (2008). The quantitative/qualitative divide revisited: A study of published research, doctoral program curricula, and journal editor perceptions. 19(3), 383-403.

Catalogs, R., Monitor, F., \& Outlook, R. E. (2000). Making anticorruption agencies more effective. Finance \& Development.

Creswell, J. W., \& Creswell, J. D. (2017). Research design: Qualitative, quantitative, and mixed methods approaches: Sage publications.

Crosby, B. C., \& Bryson, J. M. (2005). Leadership for the common good: Tackling public problems in a shared-power world (Vol. 264): John Wiley \& Sons. 
Dalton, R. J., Powell Jr, G. B., \& Strøm, K. (2014). Comparative politics today: a world view: Pearson Education Limited.

Duke, O. O., \& Agbaji, D. D. (2017). The pursuit of good governance and the anti-financial corruption blitz in Nigeria: A study of the Economic and Financial Crimes Commission (EFCC)(2003-2016). Asian Research Journal of Arts \& Social Sciences, 1-16.

Eyisi, A., \& Ezuwore, C. (2014). The impact of forensic auditors in corporate governance. Research Journal of Finance and Accounting, 5(8), 31-39.

Eyo, A. (2017). Corruption and the Challenge to Sustainable Public Procurement (SPP): A Perspective on Africa. Eur. Procurement \& Pub. Private Partnership L. Rev., 12, 253.

Fagbadebo, O. (2007). Corruption, governance and political instability in Nigeria. African Journal of Political Science and International Relations, 1(2), 028-037.

Healy, M., \& Perry, C. J. Q. M. R. A. I. J. (2000). Comprehensive criteria to judge validity and reliability of qualitative research within the realism paradigm.

Hope Sr, K. R. (2017). Fighting corruption in developing countries: Some aspects of policy from lessons from the field. Journal of Public Affairs, 17(4), e1683.

Ijewereme, O. B. (2015). Anatomy of Corruption in the Nigerian Public Sector. SAGE Open, 5(2). doi:10.1177/2158244015581188

Izedomin, F., \& Mgbame, C. (2011). Curbing financial frauds in Nigeria, a case for forensic accounting. African journal of humanities and society, 1(12), 52-56.

Karwai, S. (2002). Bank fraud: Can Shari'ah prevent it. Journal of business administration, 2(1), 62-78.

Kpundeh, S. J. (1998). Political will in fighting corruption. Corruption and integrity improvement initiatives in developing countries, 91-110.

Kpundeh, S. J. (2000). Corruption and corruption control in Africa. Paper presented at the a Workshop organized by the Gulbenkian Foundation on Democracy and Development in Africa, Lisbon.

Mansor, N. (2015a). Concomitant debacle of fraud incidences in the Nigeria public sector: Understanding the power of fraud triangle theory. International journal of academic research in business and social sciences, 5(9), 2222-6990.

Mansor, N. (2015b). Fraud triangle theory and fraud diamond theory. Understanding the convergent and divergent for future research. International Journal of Academic Research in Accounting, Finance and Management Science, 1, 38-45.

Mukoro, D. (2013). The role of forensic accountants in fraud detection and national security in Nigeria. Manager(17), 90-106.

Okekeocha, C. (2013). A case study of corruption and public accountability in Nigeria.

Okoye, E. I. (2016). Anatomy of fraud and corruption in Nigeria: A search for the pandora box and panacea. Okoye, El (2016). Anatomy of Fraud and Corruption in Nigeria: A Search for the Pandora Box and Panacea. 32nd Inaugural Lecture of Nnamdi Azikiwe University, Awka, Anambra State, Nigeria.

Okoye, E. I., \& Gbegi, D. (2013). Forensic accounting: A tool for fraud detection and prevention in the public sector.(A study of selected ministries in Kogi state).

Onuora, J., Akpoveta, B., \& Agbomah, D. (2018). Public sector accounting fraud in Nigeria. Accounting and Taxation Review, 2(4).

Quah. (2004). Best practices for curbing corruption in Asia. 11, 1-4.

Quah. (2006). Curbing Asian corruption: an impossible dream? , 105(690), 176.

Quah. (2008). Curbing corruption in India: An impossible dream?, 16(3), 240-259.

Quah, J. S. (2016). Controlling corruption in asian countries. Routledge handbook of corruption in Asia.

Quah, J. S. (2017). Singapore's success in combating corruption: lessons for policy makers. Asian Education and Development Studies, 6(3), 263-274.

Ritchie, J., Lewis, J., Nicholls, C. M., \& Ormston, R. (2013). Qualitative research practice: A guide for social science students and researchers: sage.

Stapenhurst, R., \& Kpundeh, S. J. (1999). Curbing corruption: Toward a model for building national integrity: The World Bank.

Taiwo, J., Agwu, E., Babajide, A., \& Isibor, A. A. (2016). Growth of bank frauds and the impact on the Nigerian banking industry. Journal of Business management and economics, 4, 12. 
Ugoani, J. (2015). Political will and anticorruption crusade management in Nigeria. Paper presented at the University of Sri Jayewardenepura, Sri Lanka, 12th International Conference on Business Management (ICBM).

Williams, R., \& Doig, A. (2004). A Good Idea Gone Wrong. Anti-Corruption Commissions In The TwentyFirst Century. Bergen: The Christian Michelsen Institute.

Wolfe, D. T., \& Hermanson, D. R. (2004). The fraud diamond: Considering the four elements of fraud. 